\title{
An Experimental Analysis on the Impact of Elaboration Learning on Learning Achievement and Critical Thinking
}

\author{
Endra Priawasana ${ }^{1,2, *}$, I Nyoman Sudana Degeng ${ }^{1}$, Sugeng Utaya ${ }^{1}$, Dedi Kuswandi ${ }^{1}$ \\ ${ }^{1}$ Department of Educational Technology, Faculty of Educational Science, State University of Malang, Indonesia \\ ${ }^{2}$ Department of Biology Education, Faculty of Math and Science Education, Institute of Teacher and Training PGRI of Jember, \\ Indonesia
}

Received April 6, 2020; Revised May 4, 2020; Accepted June 4, 2020

Copyright $(02020$ by authors, all rights reserved. Authors agree that this article remains permanently open access under the terms of the Creative Commons Attribution License 4.0 International License

\begin{abstract}
The learning strategy contributes significantly to achieving learning achievements, but lectures often use many methods of learning. This fact does not match the demands of 21 st-century learning that requires creative, critical, and communicative learning. This research aims to analyze the effect of the elaboration learning strategy on students' learning outcomes and critical-thinking skills. A two-factor mixed design (learning strategy and learning achievement) was used by involving 360 students randomly selected from 10 classes of senior high schools in the area of Jember, East Java, Indonesia. Five classes as the experimental classes used the elaboration learning strategy while five others as the control classes used the web teaching approach. After three weeks of treatment, all students are tested with their critical thinking skills and the cognitive abilities of their learning outcomes. Data is processed using multivariate analysis. The results show students' learning achievements (results of learning and critical thinking) as a result of elaborated learning strategies different from the Web teaching-learning strategy. Critical thinking and student learning outcomes use elaboration strategies better than web teaching-learning strategies. The researcher has long developed the elaboration learning strategy, but very few are using it. These results prove the teacher can use this strategy as an alternative in improving students' critical thinking skills.
\end{abstract}

Keywords Elaboration Learning, Critical Thinking, Learning Achievement

\section{Introduction}

21st-century demands a student-centered learning system to enable students to think critically, creatively, communicatively, and collaboratively [1], [2]. In recent years, several research and writings on 21st-century learning have been associated with students' learning outcomes and goal orientation. However, only limited research focuses on the elaboration learning strategy, learning outcomes, and critical thinking [3], [4].

Learning strategies play a significant role in determining the quality of learning [5]. The learning outcomes of the learning process are also influenced by the quality of learning. Ideally, a better quality of learning will result in better learning outcomes, but this is difficult to realize because the quality of learning has many factors and variables, including the teacher, student, and supporting facility [5].

Learning outcomes are an indicator of the level of success of learning achievement [6]. In general, cognitive learning outcomes become the orientation of student goals; besides, there are various types of nurturant effects of each learning process [7], such as critical thinking, creativity, innovation, communication, and collaboration skills [8].

To achieve learning outcomes with such diverse effects requires a learning strategy that is able to combine a variety of approaches. One of the well-known learning strategies that can organize learning materials with a variety of methods is the elaboration learning strategy [9]. This learning strategy organizes learning by providing a framework of content in the field of study being taught, giving a complete picture of the topic of the material, and choosing the subject to be a specific part [5].

The absence of research that focuses on the elaboration learning strategy on learning outcomes and critical thinking leads us to conduct this research with the following research questions: (1) does the elaboration 
learning strategy have a different effect from the web teaching-learning strategy on students' learning outcomes and critical-thinking skills? And (2) does the difference in the impact between the elaboration and web teaching-learning strategies lie in the students' learning outcomes and critical-thinking skills?

We carried out an experiment on the effect of learning strategies on learning achievements, consisting of learning outcomes and critical-thinking skills. The classes were randomly assigned to levels of the elaboration learning strategy and the web teaching-learning strategy. Based on the previous research, we hypothesized that (1) the elaboration learning strategy has different effects from the web teaching approach on students' learning outcomes and critical-thinking skills and (2) the difference in the impact between the elaboration and web teaching-learning strategies lies in the students' learning outcomes and critical-thinking skills.

\section{Literature Review}

\subsection{Elaboration Learning Strategy}

Elaboration is a strategy of organizing learning from a general to specific order. The elaboration theory is a theory of learning design based on arguments that lessons must be arranged from simple to complex materials [10], [11]. Learning organization based on the elaboration theory presents strategies that are in line and in accordance with the schematic concept that knowledge will be arranged hierarchically from general to specific parts and interrelated [5].

The elaboration learning strategy is based on several principles that form the basis of organizing learning contents [12], including (1) presenting the content framework (epitome) in the initial phase of the entire learning process, (2) elaborating the parts covered in the content framework, (3) presenting the most important part, (4) related to the level of depth and comprehensiveness of elaboration, (5) associated with the presentation of the synthesizer which is carried out in stages, that is, after each elaboration, to show the relationship between the more detailed constructs that have just been taught, (6) related to the presentation of the type of synthesizer that serves as a hook for units of concepts, procedures, or principles adapted to the kind of content in the field of study, and (6) providing a summary for a review of the contents of the study field that has been studied that should be given before the presentation of the synthesizer.

In addition to these principles, according to Degeng [5], there are several steps in organizing learning using the elaboration learning strategy. The first step is the presentation of a content framework where learning begins by presenting a content framework, a structure that contains the essential parts of the field of study. The second is an elaboration of the first stage, elaborating on each part of the content framework starting from the most important one. The elaboration of each section ends with a summary and synthesizer relating to constructs taught (Internal Synthesis). The third is giving a review and external synthesis. At the end of the first stage of elaboration, an overview is given, followed by an external synthesizer. The report contains brief notions of the constructs taught in elaboration and external synthesizers. The fourth step is the second-stage elaboration. After the first elaboration ends and is integrated with the content framework, learning is continued to the second stage of elaboration, which elaborates the parts of the first elaboration with the aim of bringing students to the level of depth as specified in the learning objectives. As with the first-stage elaboration, each second-stage elaboration is accompanied by an internal summary and synthesizer. The next step is to give a review of the external synthesis. At the end of the second elaboration, an external outline and integration are provided, as in the first elaboration. After all the second-stage elaborations have been presented, synthesized, and integrated into the content framework, this pattern will be repeated for the third-stage elaboration and so on according to the level of depth set by the learning objectives. In the final stage of learning, the content framework is re-presented to synthesize the entire contents of the field of study that has been taught.

\subsection{Biology Learning}

Biology is a branch of science that studies the natural phenomena of living things and life [13]. Study topics discussed in biology include substances that makeup is living things, materials needed by living things, and various matters related to the relationship between living things and their environment.

Biology is defined as a set of knowledge about objects and natural phenomena obtained from the results of the thoughts and investigations of scientists conducted with experimental skills [14]. This definition implies that biology is a branch of knowledge that is built based on observations and classifications, usually arranged and verified, which involves the application of reasoning and data analysis to phenomena that occur in nature [14], [15].

Biology subject is one of the topics in the science family. The essence of biology is a science that uses nature with all its contents, including earth, plants, animals, and humans as its object of observations. Biology is a science that is obtained by using methods based on the representation of how to find out about nature so that biology is not only about mastering a set of knowledge in the form of facts, concepts, or principles, but also a process of discovery [14], [16].

Based on the characteristics and nature of biology that is so complex, it is necessary to have a learning strategy that is suitable for learning it [5]. The abstract 
characteristic and the broad scope make biology requires learning strategy approaches that teach theories from general matters to details or from full to specific topics. One of the methods is the elaboration learning strategy.

\subsection{Critical Thinking}

Critical thinking consists of six elements of focus, reason, inference, situation, clarity, and overview. Focus is making a decision about what is believed to clarify the available questions or issues. The idea is knowing the reasons that support or oppose decisions made based on relevant situations and facts. The inference is making reasonable or convincing conclusions. The situation is understanding the situation and always keeping the situation in mind that will help clarify the question and know the meaning of the key terms, the relevant parts as support. Clarity is explaining the meaning of words used. Lastly, Overview is stepping back and thoroughly researching the decisions taken [17].

Critical thinking is a reflection of wisdom in decision making and problem-solving about what to believe and what to do intellectually [18], [19]. In addition, critical thinking also contains characters of active discipline, skillfully conceptualizing, applying, analyzing, synthesizing, and/or evaluating information collected and/or generated by observation, experience, reflection, reasoning or communication, as a guide for beliefs and actions [20].

\section{Method}

\subsection{Participant}

Students from ten classes of senior high schools in the Jember, East Java took part in this research. Each class consisted of 36 students where five classes were treated with the elaboration learning strategy as the experimental classes (EC) and five others with the web teaching-learning strategy as the control classes (CC). This participant intake is based on a simple random sampling technique because population members are considered homogeneous.

\subsection{Design}

In the analysis stage, we investigate the effect of learning strategies on students' learning outcomes and critical-thinking skills. The independent variable in the analysis is the learning strategies consisting of elaboration and web teaching. The dependent variable is the learning achievement, which consists of students' learning outcomes and critical-thinking skills. Two-way analysis of variance (ANOVA) was employed to analyze the data. Here is the research design of the posttest-only control group design presented in table 1.

Table 1. Research Design

\begin{tabular}{|c|c|c|}
\hline Class & Treatment & Post-test \\
\hline Experiment (EC) & $\mathrm{X}$ & $\mathrm{O}$ \\
\hline Control $(\mathrm{CC})$ & - & $\mathrm{O}$ \\
\hline
\end{tabular}

EC treatment uses the elaboration learning model while $\mathrm{CC}$ uses web-teaching. The results of these two learning model implementations are measured by post-test to measure students ' learning outcomes and critical thinking.

\subsection{Data Collection Tool}

Data is collected using a test instrument of 15 questions to measure learning outcomes and six items to measure critical thinking on senior high school biology subjects. All instruments are validated by experts and have high reliability.

\section{Result}

We calculated ANOVA by using a two-factor mixed design (learning strategy and learning achievement) to determine students' learning outcomes and critical-thinking skills by learning strategies. Table 2 shows the descriptive statistics for learning strategies on learning achievements.

Table 2. Descriptive Statistics Data of Learning Outcomes

\begin{tabular}{|c|c|c|c|c|c|}
\hline \multirow{2}{*}{ Learning Strategy } & \multirow{2}{*}{$\mathrm{N}$} & \multicolumn{2}{|c|}{$\begin{array}{c}\text { Learning } \\
\text { Outcomes }\end{array}$} & \multirow{2}{*}{$\begin{array}{c}\text { Effect } \\
\text { Size }\end{array}$} & \multirow{2}{*}{ Criteria } \\
\cline { 3 - 4 } & & $\mathrm{M}$ & $\mathrm{SD}$ & & \\
\hline Elaboration & 180 & 83,81 & 4,10 & \multirow{2}{*}{2,21} & \multirow{2}{*}{ Large } \\
\hline Web-teaching & 180 & 74,63 & 4,20 & & \\
\hline
\end{tabular}

Based on table 2 shows that the learning outcomes of elaboration have a higher average rate of web-teaching. It also proves the elaboration has a significant influence on the achievement of student learning outcomes. Elaboration also has a significant impact on critical thinking students, as seen in table 3 follows.

Table 3. Descriptive Statistics Data of Critical Thinking

\begin{tabular}{|c|c|c|c|c|c|}
\hline \multirow{2}{*}{ Learning Strategy } & \multirow{2}{*}{$\mathrm{N}$} & \multicolumn{2}{|c|}{$\begin{array}{c}\text { Critical } \\
\text { Thinking }\end{array}$} & \multirow{2}{*}{$\begin{array}{c}\text { Effect } \\
\text { Size }\end{array}$} & \multirow{2}{*}{ Criteria } \\
\cline { 3 - 4 } & & $\mathrm{M}$ & $\mathrm{SD}$ & & \\
\hline Elaboration & 180 & 24,52 & 4,74 & \multirow{2}{*}{1,25} & Large \\
\hline Web-teaching & 180 & 18,93 & 4,15 & & \\
\hline
\end{tabular}

The use of ANOVA requires data to be distributed normally and varied homogeneous. Table 4 (One-Sample Kolmogorov-Smirnov Test) shows all the normal distribution data indicated by the significance value of the termination of $\mathrm{P}>0.05$. 
Table 4. Normality Test

\begin{tabular}{|c|c|c|c|c|c|}
\hline & & $\begin{array}{c}\text { Learning outcome } \\
\text { of elaboration }\end{array}$ & $\begin{array}{c}\text { Learning outcome of } \\
\text { web-teaching }\end{array}$ & $\begin{array}{c}\text { Critical thinking of } \\
\text { elaboration }\end{array}$ & $\begin{array}{c}\text { Critical thinking of } \\
\text { web-teaching }\end{array}$ \\
\hline $\mathrm{N}$ & & 180 & 180 & 180 & 180 \\
\hline \multirow{2}{*}{$\begin{array}{c}\text { Normal } \\
\text { Parameters }\end{array}$} & Mean & 83.81 & 74.63 & 24.52 & 18.93 \\
\cline { 2 - 6 } & SD & 4.102 & 4.195 & 4.747 & 4.151 \\
\hline \multicolumn{2}{|c|}{ Asymp. Sig. (2-tailed) } & $.200^{\mathrm{c}, \mathrm{d}}$ & $.200^{\mathrm{c}, \mathrm{d}}$ & $.061^{\mathrm{c}}$ & $.200^{\mathrm{c}, \mathrm{d}}$ \\
\hline
\end{tabular}

The Data of the research results also vary homogeneous with the significance value of $\mathrm{P}>0.05$, as shown in Table 5 below (Levene's Test of Equality of Error Variances).

Table 5. Homogeneity Test

\begin{tabular}{|c|c|c|c|c|}
\hline & Levene Statistic & $\mathrm{df1}$ & $\mathrm{df2}$ & Sig. \\
\hline $\begin{array}{c}\text { Learning } \\
\text { outcome }\end{array}$ & .078 & 1 & 358 & .780 \\
\hline $\begin{array}{c}\text { Critical } \\
\text { thinking }\end{array}$ & 2.607 & 1 & 358 & .107 \\
\hline
\end{tabular}

Once known as normal distribution data and homogeneous variances, the data can be analyzed using ANOVA multivariate shown in Table 6 below.

Table 6. Multivariate Test

\begin{tabular}{|c|c|c|c|c|c|}
\hline Effect & Value & F & $\begin{array}{c}\text { Hypothesis } \\
\text { of }\end{array}$ & Error df & Sig. \\
\hline Strategy & 0,607 & 276,117 & 2,000 & 357,000 & 0,000 \\
\hline
\end{tabular}

Refers to Table 6 of a multivariate test, $F=276,117$ with $\mathrm{P}=0.000$ which means that the multivariate $\mathrm{H}_{0}$ is rejected. This result shows that learning strategies have different influences on student learning achievements (learning outcomes and critical thinking) so that they need to continue univariate testing to identify differences in each variable's impact (learning outcomes and critical thinking).

Table 7. Univariate Test

\begin{tabular}{|c|c|c|c|c|}
\hline Source & $\begin{array}{c}\text { Dependent } \\
\text { Variable }\end{array}$ & $\begin{array}{c}\text { Mean } \\
\text { Square }\end{array}$ & F & Sig. \\
\hline \multirow{2}{*}{$\begin{array}{c}\text { Corrected } \\
\text { Model }\end{array}$} & $\begin{array}{c}\text { Leaning } \\
\text { outcome }\end{array}$ & 7580,844 & 440,414 & 0,000 \\
\cline { 2 - 5 } & Critical thinking & 2811,211 & 141,290 & 0,000 \\
\hline
\end{tabular}

In the univariate test as in Table 7 , for learning outcomes, $\mathrm{F}=440,414$ with $\mathrm{p}=0.000$ and for critical thinking, $\mathrm{F}=141,290$ with $\mathrm{p}=0.000$, meaning that $\mathrm{H}_{0}$ for learning outcomes and critical thinking is rejected.

Based on the results of the univariate analysis, the critical thinking provided by the elaboration learning strategy is different from that produced by the web teaching-learning strategy. Also, learning outcomes produced by the elaboration learning strategies are different from learning outcomes produced by web teaching-learning strategies.

\section{Discussion}

The results of the analysis of learning strategies using the multivariate test show very significant differences in students' learning achievements, consisting of learning outcomes and critical thinking. These results are consistent with the theory of learning strategies or models that the different uses of strategies or models in learning will give different results with varying degrees of significance [21]. These contrasting results refer to predetermined learning objectives and the accompanying effects of the learning process, such as critical thinking in the current research.

The results of the statistical analysis show that the students taught with the elaboration learning strategy obtain a higher mean than with the web teaching-learning strategy because the elaboration strategy is an essential component in instructional design. This strategy emphasizes the role of synthesizing the contents of a material. The synthesis will make learning topics more meaningful for students [22]. Meaningful learning not only provides a bigger picture of a more meaningful understanding for students but also shows tangible results to students as extensive information [23]. This makes students more motivated in learning, which increases their learning effectiveness and outcomes [24]. Effectiveness in learning directs students to their interest and attention in learning that leads to the achievement of learning objectives. Effective learning can be seen and identified through behaviors in the learning process [25], [26].

The elaboration learning strategy describes how to organize learning from a general into a specific order. Learning materials are designed from the simplest to the most complex. Through the elaboration strategy, students are guided to develop concepts in which new ideas will be meaningful and accepted by applying learning that is designed cooperatively, allowing students to interact with their environment and get more experience in learning [22].

Biology is a part of natural science, to learn which always requires interaction with the surrounding natural environment. This interaction results in very complicated and extensive biological materials. Thus, material 
mapping is needed for analysis, such as studying from simple to more complex materials. In addition, interaction with the environment in learning biology contributes to students' success in learning. This situation also can improve their critical-thinking skills [27]. One way to study complex biology in order to achieve maximum learning outcomes and improve students' critical-thinking skills is through the elaboration strategy.

Based on the results, the elaboration strategy has shown to produce better results in improving students' critical-thinking skills than the web teaching strategy as well as the learning outcomes using the two approaches are different. These results support the previous research that the elaboration strategy can facilitate students to think at a higher level, such as creative and critical thinking [28], [29]. Similar research on applying the elaboration strategy concludes that this technique helps students in mapping the material from general to more specific [3]. In addition, this strategy can increase student productivity as a solution to correct learning errors [11].

Critical-thinking skills are the process of solving problems encountered in the surrounding environment related to what to be trusted and done to find the answers to the difficulties [30]. Students who are able to think critically always research, ask questions, have the ability to think, make decisions through logical reasoning, solve problems, respect the opinions of others, be confident, and open to collaboration [31]. The elaboration learning strategy focuses on connecting information with each other, which helps students to understand the relationship between information. This indirectly trains students to think critically because, in the process of combining information, they make interpretations, classifications, discrimination, deductions, conclusions, and evaluations [3], [28].

According to the findings, the learning outcomes between the implementation of the elaboration and web teaching strategies are much different. The web teaching-learning strategy is a learning strategy that emphasizes the structure of students' prior knowledge. This strategy is suitable for history learning, which is based on chronological relationships where a sequence is made following the actual procedure or series of events [32]. The weakness of the web teaching-learning strategy is that students must have a prior knowledge structure and concept in order to improve the assimilation of the new material. Prior knowledge not only influences new coding and specific knowledge but also guides the processing and translation of information that can produce previous experience. This results in students having to find their own sequence or way in the material to be studied [33].

This research provides strong evidence that the elaboration learning strategy has different effects on learning achievements, both learning outcomes and critical-thinking skills, from the web teaching-learning strategy. However, this research has a limitation in the number of samples or the population that is still in one scope of a city. Further testing is needed with a more significant number of samples from different educational levels and a fuller population coverage area so that the results will be more complete and can be used as a comparison in implementing learning strategies in class.

\section{Conclusions}

As explained in the previous section, it can be summed up that the students taught with the elaboration strategy have different achievements (consisting of learning outcomes and critical thinking) from those taught with the web teaching-learning strategy. The critical-thinking skills produced by the elaboration learning strategy are different from those produced by the web teaching-learning strategy, as well as the learning outcomes generated are different.

\section{Acknowledgements}

We express our gratitude to BPPDN Kemenristekdikti, which has fully funded this research and all those who have contributed to the success of this research.

\section{REFERENCES}

[1] M. Oey-Gardiner et al., Era Disrupsi Peluang dan Tantangan Pendidikan Tinggi Indonesia. Jakarta Pusat: Akademi Ilmu Pengetahuan Indonesia, 2017.

[2] C. Utama, Sajidan, J. Nurkamto, and Wiranto, "Using TPACK as a framework to analyze TLC model," in Journal of Physics: Conference Series, 2019, vol. 1175, no. 1.

[3] J. Bridges, J. Stefaniak, and J. Baaki, “A Formative Design Examining the Effects of Elaboration and Question Strategy with Video Instruction in Medical Education," J. Form. Des. Learn., vol. 2, no. 2, pp. 129-143, 2018.

[4] X. Lin, "Achievement Goal Orientations as Predictors of Self-Regulated Learning Strategies of International ESL Students.," Int. J. Teach. Learn. High. Educ., vol. 31, no. 2, pp. 214-223, 2019.

[5] I. N. S. Degeng, Ilmu Pembelajaran Klasifikasi Variabel untuk Pengembangn Teori dan Penelitian, 1st ed. Bandung: Aras Media, 2013.

[6] C. H. Chen, C. Y. Huang, and Y. Y. Chou, "Effects of augmented reality-based multidimensional concept maps on students' learning achievement, motivation and acceptance," Univers. Access Inf. Soc., vol. 18, no. 2, pp. 257-268, 2019.

[7] [7] C. W. Liao, C. H. Chen, and S. J. Shih, "The interactivity of video and collaboration for learning 
achievement, intrinsic motivation, cognitive load, and behavior patterns in a digital game-based learning environment," Comput. Educ., vol. 133, no. July 2018, pp. 43-55, 2019.

[8] C. Utama, Sajidan, J. Nurkamto, and Wiranto, "A conceptual model for electronic learning cycle on schoology," in IOP Conference Series: Earth and Environmental Science PAPER, 2019, pp. 1-8.

[9] C. E. Weinstein, "Elaboration Skills as a Learning Strategy," in Learning Strategies, ACADEMIC PRESS, INC., 1978, pp. 31-55.

[10] A. Johnsey, G. R. Morrison, and S. M. Ross, "Using Elaboration Strategies Training in Instruction to Promote Generative Learning," Contemp. Educ. Psychol., vol. 5, no. 17, pp. 125-135, 1992.

[11] K. Loibl and T. Leuders, "How to make failure productive: Fostering learning from errors through elaboration prompts," Learn. Instr., vol. 62, no. February, pp. 1-10, 2019.

[12] I. N. S. Degeng and Y. hadi Miaarso, Terapan Teori Kognitif dalam Desain Pembelajaran. Jakarta: Departemen Pendidikan dan Kebudayaan Direktorat Jendral Pendidikan Tinggi, 1990.

[13] N. Großmann and M. Wilde, "Experimentation in biology lessons: guided discovery through incremental scaffolds incremental sca ff olds," Int. J. Sci. Educ., vol. 0, no. 0, pp. $1-23,2019$.

[14] C. Weng, S. Otanga, S. M. Christianto, and R. J. Chu, "Enhancing Students' Biology Learning by Using Augmented Reality as a Learning Supplement," J. Educ. Comput. Res., vol. 0, no. 0, pp. 1-24, 2019.

[15] [15] A. Çimer, "What makes biology learning difficult and effective: Students' views," Educ. Res. Rev., vol. 7, no. 3, pp. 61-71, 2012.

[16] [16] M. Kışoğlu, "An Examination of Science High School Students' Motivation towards Learning Biology and Their Attitude towards Biology Lessons," Int. J. High. Educ., vol. 7, no. 1, pp. 151-164, 2018.

[17] R. H. Ennis, "Critical Thinking Dispositions: Their Nature and Assessability," Informal Log., vol. 18, pp. 165-182, 1996.

[18] N. C. Facione and P. A. Facione, "Analyzing Explanations for Seemingly Irrational Choices: Linking Argument Analysis and Cognitive Science," Int. J. Appl. Philos., vol. 15, no. 2, pp. 267-286, 2001.

[19] N. Facione and P. Facione, "Critical thinking and clinical judgment," Crit. Think. Clin. Reason. Heal. Sci. A Teach. Anthol., pp. 1-9, 2008.

[20] P. A. Facione, C. A. Giancarlo, N. C. Facione, and J. Gainen, "The disposition toward critical thinking," J. Gen. Educ., vol. 44, no. 1, pp. 1-17, 1995.

[21] S. McQuiggan, L. Kosturko, J. McQuiggan, and J. Sabourin, Mobile Learning: A Handbook for Developers, Educators, and Learners. 2015.

[22] C. M. Reigeluth, "Elaborating the elaboration theory," Educ. Technol. Res. Dev., vol. 40, no. 3, pp. 80-86, Sep.
1992.

[23] G. Zurita, B. Hasbun, N. Baloian, and O. Jerez, "Emerging Issues in Smart Learning," pp. 1-8, 2015.

[24] E. Kostiainen, T. Ukskoski, M. Ruohotie-Lyhty, M. Kauppinen, J. Kainulainen, and T. Mäkinen, "Meaningful learning in teacher education," Teach. Teach. Educ., vol. 71, pp. 66-77, Apr. 2018.

[25] P. Setyosari, "Menciptkan Pembelajaran yang Efektif dan Berkualits," J. Inov. dan Teknol. Pembelajaran, vol. 1, no. 1, pp. 20-30, Dec. 2017.

[26] C. Utama, Sajidan, J. Nurkamto, and Wiranto, "Digital literacy as a daily activity: Preferences of the main functions of technology," Univers. J. Educ. Res., vol. 8, no. 3D, pp. 39-46, 2020.

[27] M. Shobirin, A. D. Corebima, and B. Lukiati, "Critical Thinking Skills and Students' Achievement on Biology Lesson Using Genetic Instructional Material Based on Learning Cycle 5E: A Correlation Study," J. Pendidik. Sains, vol. 7, no. 1, pp. 15-19, 2019.

[28] J. I. McSparron, A. Vanka, and C. C. Smith, "Cognitive learning theory for clinical teaching," Clin. Teach., vol. 16, no. 2, pp. 96-100, 2019.

[29] Y. Pramusinta, P. Setyosari, and D. Kuswandi, "Exploring Metacognitive and Critical Thinking Skills of Pre-Service Elementary School Teachers through Discovery Learning Method by Integrating Various Cognitive Styles," J. Educ. Gift. Young, no. December, pp. 999-1017, 2019.

[30] G. E. Robinson et al., "Empowering 21st Century Biology," Bioscience, vol. 60, no. 11, pp. 923-930, 2010.

[31] Ü. Demiral and S. Cepni, "Examining argumentation skills of preservice science teachers in terms of their critical thinking and content knowledge levels: An example using GMOs," J. Turkish Sci. Educ., vol. 15, no. 3, pp. 128-151, 2018.

[32] D. Jonassen and C. Reigeluth, Instructional design theories and models: A new paradigm of instructional theory. New York: lawren erlbaum associates Inc, 1999.

[33] H. Tillema, "Webteaching: Sequencing of subject matter in relation to prior knowledge of pupils," Instr. Sci., vol. 12, no. 4, pp. 321-332, Dec. 1983. 